\title{
KONSEP PENDIDIKAN GENDER DI DALAM ISLAM
}

\author{
Jonari Hanafi, Enjang Jamahsari \\ IAILM Suryalaya \\ jonarihanafi90@gmail.com
}

\begin{abstract}
This study aims of the current research is to figure out 1) Gender concept in education presektif; 2) The interpretation of AlQur'an in Al-Hujurat sentence 13 towards interpretation of Al Azhar by Buya Hamka; 3) Gender concept in Islam view according to Al-Qur'an in Al-Hujurat sentence 13 towards interpretation of Al Azhar by Buya Hamka. The method used to collect the data was Content Analysis, because in this research has normatif characteristic and has relation with the content of the text, that is Interpretation from interpreters in interpre the holly sentence of Al-Hujurat sentence 13. The result of this study is 1) The interpretation of Al-Qur'an in Al-hujurat sentence 13 explain that human in Alloh SWT view are same, not being one faction who exeed another faction. People can not priding upon lineage, preeminate of estae, affronting to poor man. And Alloh SWT describe that its main is being in godly. 2) In this sentence is being some concept of gender equivalence, they are : a) Alloh SWT was exlamation to al of human without differences by gender, skin tone, or another, this shown that all of human in reality are same, not being more exeed from the other. b) People can not choose in order to born at certain nation. Hence, inappropriate human being pluming him or flatter others because tribe factor or nation. c) Alloh specify other parameter to measure degree of dignity of human being, that is fear. This fear rate determine dignity and Iowliness of someone. 3) as for its implication to education of islam, among others: a) Sentences reintepretation of $\mathrm{Al}$ Qur'An and of Hadits which is diffraction of gender conducted continue (point ofview of islam). b) Curriculum national payload eliminating


dikotomis among woman and men, that way also local curriculum by being based on equivalence, balance and justice. Curriculum compiled as according to and requirement of tipologi area started from Playgroup education to the University. c) Enableness of woman clan in informal education sector like giving of facility learn to start in subdistrict level until to regency level which adapted with requirement of area.

Keywords: Gender, Education, Islam

\begin{abstract}
Abstrak
Tujuan penelitian ini adalah untuk mengetahui : 1) konsep gender dalam presektif Pendidikan; 2) tafsir al-Qur'an surat al-Hujurot ayat 13 menurut tafsir Al Azhar Karya Buya Hamka; 3) konsep gender di dalam islam berdasarkan al-Qur'an surat al-Hujurot ayat 13 menurut tafsir Al Azhar Karya Buya Hamka. Metode yang digunakan dalam penelitian ini adalah content analiysis, karena penelitian ini bersifat normatif dan berkaitan denga isi teks, yakni interpretasi para mufassir dalam menafsirkan surat al-Hujurat ayat 13. Hasil penelitian ini adalah : 1) tafsir al-Qur'an surat al-Hujurat ayat 13 menjelaskan bahwa manusia dihadapan Allah swt. sama, tidak ada satu golongan yang mengungguli golongan yang lain. Manusia tidak boleh membanggakan nasab, mengunggul-unggulkan harta dan menghina kepada orang-orang fakir. Dan Allah menerangkan bahwa keutamaan itu terletak pada takwa. 2) dalam ayat ini ada beberapa konsep kesetaraan gender, diantaranya : a) Allah menyeru seluruh manusia tanpa membedabedakan jenis kelamin, jenis kulit atau yang lainnya. Ini menunjukan bahwa seluruh umat manusia pada hakikatnya sama, tidak ada yang lebih unggul dari yang lainnya. b) Manusia tidak bisa memilih agar dilahirkan di suku atau bangsa tertentu. Karenanya, manusia tidak pantas membanggakan dirinya atau melecehkan orang lain karena faktor suku atau bangsa. c) Allah swt menetapkan parameter lain untuk mengukur derajat kemulian manusia, yaitu ketakwaan. Kadar ketakwaan inilah yang menentukan kemulian dan kehinaan seseorang. 3) adapun implikasinya terhadap pendidikan Islam, diantaranya : a) Reintepretasi ayat-ayat al-Qur'an dan hadits yang bias gender dilakukan secara
\end{abstract}


kontinu (sudut pandang Islam). b) Muatan kurikulum nasional yang menghilangkan dikotomis antara laki-laki dan perempuan, demikian pula kurikulum lokal dengan berbasis kesetaraan, keadilan dan keseimbangan. Kurikulum disusun sesuai dengan kebutuhan dan tipologi daerah yang dimulai dari tingkat pendidikan Taman KanakKanak sampai ke tingkat Perguruan Tinggi. c) Pemberdayaan kaum perempuan di sektor pendidikan informal seperti pemberian fasilitas belajar mulai di tingkat kelurahan sampai kepada tingkat kabupaten disesuaikan dengan kebutuhan daerah.

\section{A. PENDAHULUAN}

Al Qur'an yang diturunkan kepada Nabi Muhammad saw disampaikan dalam bahsa Arab menurut uslub - uslub -nya. Jadi seluruh lafadz - lafadz yang ada didalam Al Qur'an itu adalah bahasa Arab kecuali ada beberapa kata yang berasal dari bahasa lain yang telah menjadi bahasa Arab dan telah digunakan dalam bahasa Arab itu sendiri.

Lafadz - lafadz yang ada dalam Al Qur'an itu ada yang dikehendaki secara makna hakikat-nya, ada juga yang dikehendaki secara makna Majaz- nya, bahkan ada yang dikehendaki kinayah-nya. Oleh karena itu setiap kali Rosululloh menerima wahyu kemudian disampaikan kepada para Sahabat, maka beliau senantiasa memberikan penafsiran terhadap ayat yang disampaikannya itu, namun dalam metode penafsirannya adakalanya langsung disampaikan dengan lisan (Sunnah qouliyah), adakalanya langsung dengan perbuatan (Sunnah fi'liyah) dan adakalanya cukup dengan persetujuan saja (Sunnah taqririyah).

Tidak semua ayat ditafsirkan oleh Rosululloh sehingga Aisyah ra. pernah berkata :"Nabi manafsirkan hanya beberapa ayat saja, menurut petunjuk - petunjuk yang diberikan jibril". (Assidieqy. 2012 : 175).

Usaha - usaha untuk mengetahui penafsiran dari ayat - ayat Al Qur'an terus dilakukan oleh para Sahabat mengingat sangat 
pentingnya mengetahui penafsiran dari setiap ayat Al Qur'an yakni memahaminya dan menghayati maknanya.

Perkembangan penafsiran Al Qur'an ini sangat menarik untuk kita pelajari, cara berfikir serta pengetahuan mufasir yang berbeda - beda, metode penafsiran yang digunakannya juga berbeda - beda sehingga hal ini mendorong terjadinya perbedaan penafsiran serta pemahaman dari ayat - ayat Al Qur'an.

Sebagai salasatu contohnya adalah dalam menafsirkan ayat - ayat yang berkaitan dengan manusia, sehingga manusia merupakan objek penafsiran Al Qur'an yang paling besar. firman Allah dalam QS. An-Nisa' ayat 1, yang artinya :

"Hai sekalian manusia, bertaqwalah kepada Tuhanmu, yang telah menciptakan kamu dari diri (nafs) yang satu, dan darinya Allah menciptakan pasangannya dan keduanya Allah mengembangbiakkan laki-laki dan perempuan yang banyak............." (Tim Penerjemah Al Qur'an KemenagRI, 2012 :77)

Yang dimaksud dengan nafs di sini menurut mayoritas ulama tafsir adalah Adam dan pasangannya adalah istrinya yaitu Siti Hawa. Pandangan ini kemudian telah melahirkan pandangan negatif kepada perempuan dengan menyatakan bahwa perempuan adalah bagian laki-laki. Tanpa laki-laki perempuan tidak ada, dan bahkan tidak sedikit di antara mereka berpendapat bahwa perempuan (Hawa) diciptakan dari tulang rusuk Adam. Kitab-kitab tafsir terdahulu hampir bersepakat mengartikan demikian.

Kalaupun pandangan di atas diterima yang mana asal kejadian Hawa dari rusuk Adam, maka harus diakui bahwa ini hanya terbatas pada Hawa saja, karena anak cucu mereka baik laki-laki maupun perempuan berasal dari perpaduan sperma dan ovum. Allah menegaskan hal ini dalam QS. Ali Imran: 195, yang artinya :

"Maka Tuhan mereka memperkenankan permohonannya (dengan berfirman): "Sesungguhnya Aku tidak menyianyiakan amal orang-orang yang beramal di antara kamu, baik 
laki-laki atau perempuan, (karena) sebagian kamu adalah turunan dari sebagian yang lain. Maka orang-orang yang berhijrah, yang diusir dari kampung halamannya, yang disakiti pada jalan-Ku, yang berperang dan yang dibunuh, pastilah akan $\mathrm{Ku}$-hapuskan kesalahan-kesalahan mereka dan pastilah Aku masukkan mereka ke dalam surga yang mengalir sungai-sungai di bawahnya, sebagai pahala di sisi Allah. dan Allah pada sisi-Nya pahala yang baik." (Tim Penerjemah Al Qur'an Kemenag RI, 2012 :76)

Maksud dari sebagian kamu adalah turunan dari sebagian yang lain adalah sebagaimana laki-laki berasal dari laki-laki dan perempuan, Maka demikian pula halnya perempuan berasal dari laki-laki dan perempuan. kedua-duanya sama-sama manusia, tak ada kelebihan yang satu dari yang lain tentang penilaian iman dan amalnya.

Adanya perbedaan antara laki-laki dan perempuan tidak dapat disangkal karena memiliki kodrat masing-masing. Perbedaan tersebut paling tidak dari segi biologis. Sebagaimana Allah menjelaskan dalam Al-Qur'an Surat An Nisa ayat 32, yang artinya :

"Dan janganlah kamu iri hati terhadap apa yang dikaruniakan Allah kepada sebahagian kamu lebih banyak dari sebahagian yang lain. (karena) bagi orang laki-laki ada bahagian dari pada apa yang mereka usahakan, dan bagi para wanita (pun) ada kebahagiaan dari apa yang mereka usahakan, dan mohonlah kepada Allah sebagian dari karunia-Nya. Sesungguhnya Allah Maha mengetahui segala sesuatu". (Tim Penerjemah Al Qur'an Kemenag RI, 2012 :83)

Ayat di atas mengisyaratkan perbedaan, dan bahwa masingmasing memiliki keistimewaan. Walaupun demikian, ayat ini tidak menjelaskan apa keistimewaan dan perbedaan itu. Namun dapat dipastikan bahwa perbedaan yang ada tentu mengakibatkan fungsi utama yang harus mereka emban masingmasing. Di sisi lain dapat pula dipastikan tiada perbedaan dalam tingkat kecerdasan dan kemampuan berfikir antara kedua jenis 
kelamin itu. Al-Qur'an memuji ulul albab yaitu yang berzikir dan memikirkan tentang kejadian langit dan bumi. Zikir dan fikir dapat mengantar manusia mengetahui rahasia-rahasia alam raya. Ulul albab tidak terbatas pada kaum laki-laki saja, tetapi juga kaum perempuan, karena setelah al-Qur'an menguraikan sifatsifat ulul albab ditegaskan melaui surat Ali Imron ayat 195 yang artinya:

"Maka Tuhan mereka mengabulkan permintaan mereka dengan berfirman; "Sesungguhnya Aku tidak akan menyianyiakan amal orang yang beramal di antara kamu, baik lelaki maupun perempuan". (Tim Penerjemah Al Qur'an Kemenag RI, $2012: 76)$.

Ini berarti bahwa kaum perempuan sejajar dengan laki-laki dalam potensi intelektualnya, mereka juga dapat berpikir, mempelajari kemudian mengamalkan apa yang mereka hayati dari zikir kepada Allah serta apa yang mereka pikirkan dari alam raya ini.

Jenis laki-laki dan perempuan sama di hadapan Allah memang ada ayat yang menegaskan bahwa Para laki-laki (suami) adalah pemimpin para perempuan (istri) seperti firman Allah dalam surat An Nisa ayat 34: yang artinya bahwa;

Kaum laki-laki itu adalah pemimpin bagi kaum wanita, oleh karena Allah telah melebihkan sebahagian mereka (laki-laki) atas sebahagian yang lain (wanita), dan karena mereka (laki-laki) telah menafkahkan sebagian dari harta mereka. (Tim Penerjemah Al Qur'an Kemenag RI, 2012 :84)

Walaupun ada ayat seperti ini, kepemimpinan ini tidak boleh mengantarnya kepada kesewenang-wenangan, karena dari satu sisi al-Qur'an memerintahkan untuk tolong menolong antara laki-laki dan perempuan dan pada sisi lain al-Qur'an memerintahkan pula agar suami dan istri hendaknya mendiskusikan dan memusyawarahkan persoalan mereka bersama.

Sepintas terlihat bahwa tugas kepemimpinan ini merupakan keistimewaan dan derajat tingkat yang lebih tinggi dari 
perempuan. Bahkan ada ayat yang mengisyaratkan tentang derajat tersebut yaitu firman-Nya pada surat Al Baqoroh:228) yang artinya :

"Para istri mempunyai hak seimbang dengan kewajibannya menurut cara yang ma'ruf, akan tetapi para suami mempunyai satu derajat/tingkat atas mereka (para istri)" (Tim Penerjemah Al Qur'an Kemenag RI, 2012 :36)

Kata derajat dalam ayat di atas menurut Imam Thabary adalah kelapangan dada suami terhadap istrinya untuk meringankan sebagian kewajiban istri. Al-Qur'an secara tegas menyatakan bahwa laki-laki bertanggungjawab untuk memenuhi kebutuhan hidup keluarganya, karena itu, laki-laki yang belum memiliki kemampuan material dianjurkan untuk menangguhkan perkawinan. Namun bila perkawinan telah terjalin dan penghasilan manusia tidak mencukupi kebutuhan keluarga, maka atas dasar anjuran tolong menolong yang dikemukakan di atas, istri hendaknya dapat membantu suaminya untuk menambah penghasilan.

Jika demikian halnya, maka pada hakikatnya hubungan suami dan istri, laki-laki dan perempuan adalah hubungan kemitraan. Dari sini dapat dimengerti mengapa ayat-ayat AlQuran menggambarkan hubungan laki-laki dan perempuan, suami dan istri sebagai hubungan yang saling menyempurnakan yang tidak dapat terpenuhi kecuali atas dasar kemitraan. Hal ini diungkapkan al-Qur'an dengan istilah ba'dhukum mim ba'dhi sebagian kamu (laki-laki) adalah sebagian dari yang lain (perempuan). Istilah ini atau semacamnya dikemukakan kitab suci al-Qur'an baik dalam konteks uraiannya tentang asal kejadian laki-laki dan perempuan (QS. Ali Imran, 3:195), maupun dalam konteks hubungan suami istri (QS. An-Nisa, 3:21) serta kegiatan-kegiatan sosial (QS. At-Taubah, 9:71).Kemitraan dalam hubungan suami istri dinyatakan dalam hubungan timbal balik: "Istri-istri kamu adalah pakaian untuk kamu (para suami) dan kamu adalah pakaian untuk mereka" (QS. Al-Baqarah, 2:187), sedang dalam keadaan sosial 
digariskan: "Orang-orang beriman, laki-laki dan perempuan, sebagian mereka adalah penolong bagi sebagian yang lain, mereka menyuruh (mengerjakan yang ma'ruf) dan mencegah yang munkar" (QS. At-Taubah, 9:71). Pengertian menyuruh mengerjakan yang ma'ruf mencakup segi perbaikan dalam kehidupan, termasuk memberi nasehat, saran kepada penguasa, sehingga dengan demikian, setiap laki-laki dan perempuan hendaknya mampu mengikuti perkembangan masyarakat agar mampu menjalankan fungsi tersebut atas dasar pengetahuan yang mantap. Mengingkari pesan ayat ini, bukan saja mengabaikan setengah potensi masyarakat, tetapi juga mengabaikan petunjuk kitab suci.

Dalam al-Qur'an ada beberapa isu kontroversi yang berkaitan dengan konsep relasi gender, antara lain asal-usul penciptaan perempuan, konsep kewarisan, persaksian, poligami, hak-hak reproduksi, talak perempuan serta peran perempuan dalam publik. Secara sepintas, teks-teks tersebut mengesankan adanya bentuk ketidakadilan bagi kaum perempuan. Akan tetapi, jika disimak lebih mendalam dengan menggunakan metode penafsiran yang tepat dan dengan memperhatikan asbab annuzul, maka dapat dipahami bahwa ayat-ayat tersebut merupakan suatu proses dalam mewujudkan keadilan dan kesetaraan secara konstruktif di dalam masyarakat. Masih dalam penafsiran surat an-Nisa ayat 34 , bila dikaji lebih jauh lagi, idealnya dalam suatu komunitas, supaya terjadi keseimbangan dan stabilisasi pastilah ada seorang pemimpin yang bertanggung jawab untuk kelangsungan komunitas tersebut.

Dalam konteks ayat, komunitas tersebut adalah sebuah keluarga, yang mana laki-laki di tempatkan sebagai pemimpinnya. Seorang pemimpin tidak menunjuk kepada superioritas, melainkan memberi perlindungan untuk menciptakan kemaslahatan. Kata fadhala dalam ayat tersebut berarti kelebihan. Kelebihan yang dimiliki oleh laki-laki bukan pula menunjuk kepada superioritas laki-laki, mengingat kata ba'dlukum 'ala ba'din, 'sebagian' laki-laki mempunyai 
kelebihan di banding dengan 'sebagian' perempuan. Tidak menutup kemungkinan bahwa sebagian perempuan memiliki kelebihan di banding sebagian laki-laki. Sebenarnya tanggung jawab utama seorang perempuan adalah melahirkan anak. Ini menjadi sangat penting karena eksistensi manusia bergantung kepadanya. Maka semua merupakan tanggung jawab laki-laki dalam keluarga maupun dalam masyarakat. Di sinilah laki-laki sebagai qawam menyediakan segala sesuatu yang dibutuhkan oleh seorang perempuan dalam menunaikan kewajibannya secara nyaman terutama perlindungan fisik dan nafkah materi.

Al-Qur'an dengan sangat jelas menyebutkan bahwa tidak ada perbedaan antara laki-laki dan perempuan kecuali ketaqwannya. Surat al-Hujurat ayat:13

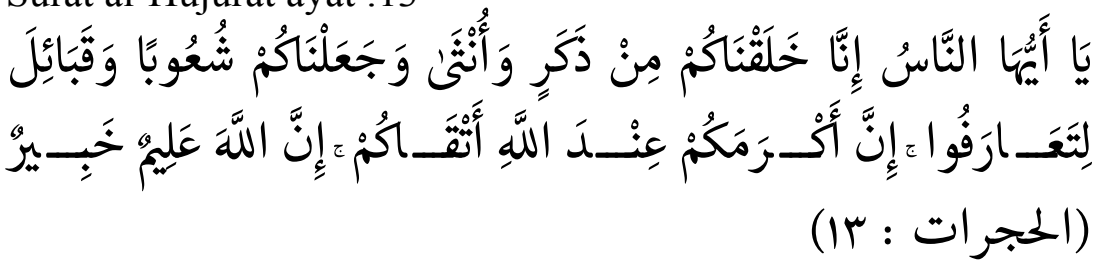

Artinya:

"Hai manusia, kami telah menciptakan kamu dari laki-laki dan perempuan, dan Kami jadikan kamu berbangsa-bangsa dan bersuku-suku supaya kamu saling mengenal. Sesungguhnya yang paling mulia diantara kamu disisi Allah adalah yang paling taqwa". (Tim Penerjemah Al Qur'an Kemenag RI, 2012 :517)

Dari penjelasan di atas, bisa dilihat bahwa Islam adalah agama yang sangat menjaga kesetaraan dan keadilan. Islam juga sangat menghargai dan menjunjung tinggi harkat dan martabat kaum perempuan.

Sementara yang menyebar dikalangan umat islam saat ini, masih banyak yang tidak setuju akan adanya kesataraan gender, mereka memahami gender sebagai sesuatu yang berasal dari barat dan berlawanan dengan ajaran islam tanpa memahami lebih jauh tentang gender itu sendiri, tidak sedikit orang-orang muslim yang tidak setuju dengan gender apalagi orang-orang 
yang berada dalam lingkungan pondok pesantren salafi, mereka menolak keras akan adanya kesetaraan gender.

Maka dari itu penulis mencoba menjelaskan tentang kesetaraan gender dari sudut keislaman dengan menggunakan landasan al-Qur'an surat al-Hujurat ayat 13 yang menunjang akan pemahaman kesetaraan gender,yang di tuangkan dalam sebuah penelitian yang berjudul : "Konsep Pendidikan Gender Berdasarkan Al-Qur'an Surat Al-Hujurot Ayat 13(Studi Analisis terhadap Tafsir Al Azhar Karya Buya Hamka)"

\section{Konsep Pendidikan}

\section{Pengertian Pendidikan}

Banyak sekali orang yang mendefinisikan pendidikan, hal ini menunjukan betapa pentingnya pendidikan dalam tatanan kehidupan manusia. Ahmad tafsir (2012: 33 ) menyatakan bahwa Sekitar 600 tahun sebelum masehi, orang Yunani sudah menyatakan bahwa pendidikan adalah sebuah usaha untuk membantu manusia menjadi manusia.

Endang Sumantri (2006: 54) mengutip kata - kata Ki Hajar Dewantara yang mengartikan pendidikan sebagai daya upaya untuk memajukan nilai, pikiran serta jasmani anak, agar dapat memajukan kesempurnaan hidup yaitu hidup dan menghidupkan anak yang selaras dengan alam dan masyarakatnya.

Selain itu, Endang Sumantri (2006: 54) juga mengutip beberapa pendapat ahli dalam mendefinisikan arti kata pendidikan sebagai berikut :

1) Abdurrohman Al Bani:

Pendidikan adalah menjaga dan memelihara fitrah anak menjelang balig, mengembangkan seluruh potensi dan kesiapan yang bermacam - macam, mengarahkan seluruh fitrah dan potensi menuju kebaikan dan kesempurnaan secara bertahap. (An- Nahlawi, $1989: 32)$ 
2) John Dewey : Pendidikan adalah proses hidup yang berlangsung terus menerus ke arah kesempurnaan (Hambali, 1996 :3)

3) Hasan Langulung : Pendidikan adalah pewarisan kebudayaan dan pengembangan potensi - potensi (Langulung, 1987 :4)

Dalam perspektif Islam, pendidikan disebutkan dengan berbagai macam istilah sehingga dalam Al Qur'an terdapat empat kata yang mempunyai arti pendidikan ditambah satu kata lagi terdapat dalam Hadits. Istilah istilah itu adalah :

1) At Tarbiyah

Yang dimaksud dengan Tarbiyah adalah proses pengembangan dan bimbingan jasad, akal, dan jiwa yang dilakukan secara berkelanjutan sehingga mutarabbi (anak didik) bisa dewasa dan mandiri untuk hidup di tengah masyarakat. ( Ath- Thabari, 67-68)

Tarbiyah juga diartikan sebagai kegiatan yang disertai dengan penuh kasih sayang, kelembutan hati, perhatian, bijak dan menyenangkan tidak membosankan (Al Maraghi opcit :34)

Dalam keterengan yang lain disebutkan juga bahwa Tarbiyah adalah proses yang dilakukan dengan pengaturan yang bijak dan dilaksanakan secara bertahap dari yang mudah kepada yang sulit. ( Ath-Thabari 34)

2) At Ta'lim

Yang dimaksud dengan at Ta'lim adalah proses pemberitahuan sesuatu dengan berulang - ulang dan sering sehingga muta'alim dapat mempresepsikan maknanya dan berbekas pada dirinya ( Al Ashrahani, Opict : 356)

3) At Tadris

Untuk memahami kata Tadris kita bisa mengambil dari kesimpulan Endang Sumantri dalam bukunya yaitu : 
Tadris adalah suatu bentuk kegiatan yang dilakukan mudaris untuk membacakan dan menyebutkan sesuatu kepada Mutadariis dengan berulang - ulang dan sering, disertai dengan mempelajari, mengungkap, menjelaskan dan mendiskusikan dengan bertujuan agar materi yang dibacakan atau disampaikan itu mudah dihafal dan diingat.(Endang Sumantri 2006 :58)

\section{4) At Tahdzib}

Yaitu pendidikan yang bertujuan untuk membersihkan atau meghilangkan sesuatu dari hal - hal yang tidak layak dan tidak pantas, serta meperbaikinya dengan hal - hal yang baik.

Definisi pendidikan menurut Ki Hajar Dewantara yang menjadikan penbentukan budi pekerti sebagai tujuan pendidikan yang pertama dan utama selaras dengan tujuan pendidikan nasional Indonesia sebagaimana tercantum dalam Undang-undang Republik Indonesia Nomor 20 tahun 2003 tentang Sistem Pendidikan Nasional, pasal 3, yakni :

Pendidikan nasional berfungsi meengembangkan

kemampuan dan membentuk watak serta peradaban bangsa yang bermartabat dalam rangka mrncerdaskan kehiidupan bangsa, bertujuan untuk berkembangnya potensi peserta didik agar menjadi manusia yang berimandan bertakwa kepada Tuhan Yang Maha Esa, berakhlak mulia, sehat, berilmu, cakap, kreatif, mandiri, dan menjadi warga negara yang demokratis serta bertanggung jawab (Anonimous, $2009: 6$ )

Muhammad Natsir sebagaimana dikemukakan oleh Azra mengemukkan bahwa pendidikan adalah 'suatu pimpinan jasmani dan rohani menuju kesempurnaan dan kelengkapann arti kemanusiaan dengan arti sesungguhnya' (Azra, 2012 : 5) dalam definisi ini, Muhammad Natsir menekankan bahwa pendidikan itu harus dilakukan secara utuh terhadap seluuruh unsur yang menyusun individu, yakni jasmani dan rohani. Selain itu, dalam definisi ini juga 
Muhammad Natsir menyatakan bahwa jasmani dan rohani manusia belum memiliki kesempurnaan jika seluruh potensi jasmani dan rohani tersebut belum dikembangkan melalui proses pendidikan. Untuk itulah, maka manusia yang jasmaninya dan ruhaninya telah berkembang secara optiomal melalui pendidikan tersebut manusia yang utuh (insan kamil).

Berdasarkan beberapa definisi di atas, dapat disimpulkan bahwa pendidikan adalah usaha untuk mengambangkan seluruh potensi yang dimiliki individu sehingga menghasilkan individu yang berbudi luhur dan berbudaya tinggi sehingga ia dapat hidup dengan baik dalam lingkungannya.

\section{Tujuan Pendidikan secara Umum}

Pendidikan akan dinyatakan berhasil jika telah mencapai tujuan - tujuan yang telah di tetapkan. Eka priatin mengutip dari perkataan Hummel (1977) menyebutkan bahwa Tujuan pendidikan harus mengandung tiga nilai :

1) Autonomy, yaitu memberi kesadaran, pengetahuan dan kemampuan secara maksimal kepada Individu maupun kelompok, untuk dapat hidup mandiri dan hidup bersama dalam kehidupan yang lebih baik.

2) Equity, yaitu pendidikan tersebut harus memberikan kesempatan kepada seluruh Masyarakat untuk dapat berpartisipasi dalam kehidupan berbudaya dan kehidupan berekonomi dengan memberi pendidikan dasar yang sama.

3) Survival, yaitu dengan pendidikan akan menjamin pewarisan kebudayaan dari satu generasi kepada Generasi berikutnya.

Sementara itu Eka Priatin juga mengutip perkataan para ahli yang lainnya seperti yang dikemukakan oleh Langeveld (1980) bahwa ada beberapa jenis tujuan pendidikan, sebagai berikut : 
1) Tujuan Umum

Tujuan umum adalah merupakan sesuatu yang akan dicapai dalam sebuah kegiatan pendidikan. Kedewasaan merupakan salasatu tujuan pendidikan. Berarti semua kegiatan pendidikan harus diarahkan kepada pendewasaan manusia untuk mencapau tujuan umum tersebut.

2) Tujuan Khusus

Tujuan Khusus meupakan penjabaran khusus dari tujuan umum. Seperti ketika tujuan umum pendidikan adalah kedewasaan maka secara khususnya yang dimaksud dengan dewasa disini adalah kedewasaan yang bersifat universal diberi bentuk yang nyata berupa kedewasaan yang berhubungan dengan kebangsaan, kebudayaan, agama dan sistem Politik.

3) Tujuan Insidental

Tujuan Insidental yaitu tujuan yang sifatnya menyangkut suatu peristiwa khusus. Tujaun insidental ini terkadang sulit dicari hubungannya dengan tujuan umum, akan tetapi tetap mengarah kepada pencapaian dan tujuan umum yang telah ditetapkan.

4) Tujuan Sementara

Tujuan sementara merupakan tujuan yang terdapat dalam langkah - langkah untuk mencapai tujuan umum. Dengan adanya tujuan sementara ini memberikan kesempatan kepada pendidik untuk dapat menguji nilai yang ingin dicapainya dengan perbuatan nyata.

5) Tujuan tidak lengkap

Tujuan tidak lengkap merupakan tujuan yang berhubungan dengan salahsatu dari aspek pendidikan. Dikatakan tidak lengkap karena hanya berhubungan dengan salasatu aspek pendidikan saja berarti dengan aspek lainnya tidak ada hubungan. 


\section{6) Tujuan Perantara}

Yaitu tujuan yang melayani tujuan pendidikan yang lainnya. Jadi tujuan ini merupakan alat atau sarana untuk mencapai tujuan pendidikan yang lain.

\section{Tujuan Pendidikan Nasional}

Tujuan Pendidikan Nasional adalah mencerdaskan kehidupan bangsa dan mengembangkan manusia Indoensia seutuhnya, yaitu manusia yang beriman dan bertaqwa terhadap Tuhan Yang Maha Esa dan berbudi pekerti luhur, memiliki pengetahuan dan keterampilan, kesehatan jasmani dan rohani, kepribadian yang mantap dan mandiri serta rasa tanggung jawab kemasyarakatan dan kebangsaan.

Dengan adanya pendidikan, maka akan timbul dalam diri seseorang untuk berlomba - lomba dan memotivasi diri kita untuk lebih baik dalam segala aspek kehidupan. Pendidikan merupakan salah satu syarat untuk lebih memajukan pemerintah ini, maka usahakan pendidikan mulai dari tingkat SD sampai pendidikan di tingkat Universitas.

Pada intinya pendidikan itu bertujuan untuk membentuk karakter seseorang yang beriman dan bertakwa kepada Tuhan Yang Maha Esa. Akan tetapi disini pendidikan hanya menekankan pada intelektual saja, dengan bukti bahwa adanya UN sebagai tolak ukur keberhasilan pendidikan tanpa melihat proses pembentukan karakter dan budi pekerti anak.

Adapun tujuan pendidikan nasional dalam UUD 1945 hal 105 (versi Amandemen)

1) Pasal 31, ayat 3 menyebutkan, "Pemerintah mengusahakan dan menyelenggarakan satu sistem pendidikan nasional, yang meningkatkan keimanan dan ketakwaan serta ahlak mulia dalam rangka mencerdaskan kehidupan bangsa, yang diatur dengan undang-undang." 
2) Pasal 31, ayat 5 menyebutkan, "Pemerintah memajukan ilmu pengetahuan dan teknologi dengan menunjang tinggi nilai-nilai agama dan persatuan bangsa untuk kemajuan peradaban serta kesejahteraan umat manusia."

3) Tujuan Pendidikan Nasional dalam Undang-Undang No. 20, Tahun 2003 Jabaran UUD 1945 tentang pendidikan dituangkan dalam Undang-Undang No. 20, Tahun 2003. Pasal 3 menyebutkan,

"Pendidikan nasional berfungsi mengembangkan kemampuan dan membentuk watak serta peradaban bangsa yang bermartabat dalam rangka mencerdaskan kehidupan bangsa, bertujuan untuk berkembangnya potensi peserta didik agar menjadi manusia yang beriman dan bertakwa kepada Tuhan Yang Maha Esa, berakhlak mulia, sehat, berilmu, cakap, kreatif, mandiri, dan menjadi warga negara yang demokratis serta bertanggung jawab."

\section{Konsep Dasar Pendidikan}

Banyak para ahli yang mengemukanan pendapatnya tentang Konsep dasar pendidikan, diantaranya adalah :

1) John Dewey

Perjalanan kehidupan manusia tidak selamanya berjalan sesuai dengan apa yang diinginkan, terkadang manusia tidak mengetahui apa alasannya dia melakukan suatu perbuatan. Jika kita mau bercermin pada pendapat yang dikemukakan oleh Paulo Freire, maka kita akan dapat membaca pikiran seseorang. Apakah ia termasuk orang yang berkesadaran magic, naif atau kritis.

Sebagai Guru, Dosen dan tenaga kependidikan, kita harus bisa membuat format pola pendidikan untuk mengantarkan peserta didik kepada kesadaran yang 
lebih tinggi. Diantara format pendidikan tersebut adalah kita berusaha memanusiakan manusia.

John Dewey sebagai salaseorang tokoh pendidikan yang berkebangsaan Amerika mencoba menawarkan sebuah format Pola pendidikan partisifatif dengan tujuan memberdayakan peserta didik dalam jalannya proses pendidikan.

Pola ini dapat mendorong peserta didik untuk dapat berhadapan dengan realita yang ada dilingkungannya sehingga peserta didik mampu mengintegrasikan antara pengalaman dengan pengetahuannya.

2) Aristatolisi

Aristatolisi sering mengungkapkan bahwa manusia adalah Zoon Politicon yaitu makhluk yang tidak bisa lepas dari masyarakat dan akan selalu tergantung dengan masyarakat itu beserta sistem sistem yang ada. Namun pada kenyataanya ternyata muncul bahwa manusia adalah homo homini lupus yaitu satu orang manusia memakan manusia lainnya. Hal ini muncul akibat daripada manusia itu sendiri, diamana manusia diciptakan dalam keadaan yang berbeda - beda ada yang kuat ada yang lemah, ada yang kaya dan adapula yang miskin, ada yang berkuasa dan ada yang tuntuk. Golongan yang lebih tinggi akan senantiasa menekan Golongan yang ada di bawahnya.

Sejarah telah mencatat bahwa telah banyak peristiwa yang terjadi berupa pemberontakan pemberontakan terhadap aturan - aturan yang sudah berlaku di tengah - tengah masyarakat, seperti Markisme, leninisme hingga pemberontakan yang bersifat lunak, seperti gerakan yang dibangun oleh Habermasisme yang berjuang demi persamaan (egaliterisme). Akan tetapi semuanya telah ditolak 
oleh takdir masyarakatnya karena semuanya hanya berakhir dengan mendorong manusia untuk menjadi Homini lupus.

Selain yang telah digambarkan diatas, masih ada dua unsur yang sangat penting yaitu selain individu ada sebuah masyarakat yang merupakan gabungan dari berbagai Individu yang membentuk suatu kelompok serta norma - norma tersemdiri. Unsur yang kedua adalah Negara yang merupakan kesatuan bangsa yang mempunyai aturan hukum yang jelas dan dapat memaksakan aturan tersebut kepada Masyarakatnya ( warga Negara)

Disini pendidikan berperan dengan melatih individu - individu supaya bisa membangun masyarakat yang lebih beradab. Pola konsep ini juga mengajak partisipasi dari setiap individu untuk ikut sumbangsih baik pemikiran, tenaga dan usaha untuk menciptakan masyarakat berkeadaban lewat jalur pendidikan.

3) Plato

Pada konsep yang dikemukanan oleh Plato disebutkan bahwa pendidikan merupakan proses yang ditempuh seseorang yang keluar dari gua sehingga ia mengetahui akan kebenaran, juga mengetahui ketidak benaran serta kepalsuan yang selama ini mengelabui orang - orang yang berada didalam gua tempat semula ia berada.

Pada konsep ini, pendidikan merupakan pembebasan manusia dari belenggu ketidaktahuan, kepalsuan dan ketidakbenaran. Pendidikan harus bisa mencetak manusia seutuhnya yaitu manusia yang mampu mengubah secara total sifat, pikiran dan perilakunya sehingga ia menjadi sama sekali baru bagaikan terlahir kembali. 
4) Jean Jaqquea Rosseau

Dia mengatakan semua kekurangan dan semua yang kita butuhkan saat kita lahir semua dapat dipenuhi dengan pendidikan.

\section{Konsep Gender}

\section{Pengertian Gender}

Sebelum membahas judul tentang konsep pendidikan gender dalam Islam, terlebih dahulu kita harus mengetahui dulu apa yang dimaksud dengan gender. Ketika kita sudah memahami tentang gender baru kita bisa melanjutkan pembahasan konsep pendidikan Gender.

Untuk memahami pengertian Gender kita bisa mengambil dari beberapa definisi yang telah dikemukakan oleh para Ahli, karena kita tidak bisa memberikan definisi secara sembarangan. Kata gender merupakan sebuah istilah yang tidak asing ditelinga kita. Secara harfiah kata gender berarti jenis kelamin. Gender juga dapat diartikan sebagai perbedaan - perbedaan yang tampak antara laki - laki dan perempuan dalam hal nilai dan prilaku.

Wahyudin Darmalaksana dalam makalahnya menjelaskan sebuah konsep Gender dengan mengutip dari perkataan Siti Musadah Aulia dari bukunya Islam menggugat Poligami dinyatakan sebagai berikut : "Gender adalah suatu konsep kurtural yang dipakai untuk membedakan peran, perilaku, mentalitas, dan karakteristik emosional antara laki - laki - laki dan perempuan yang berkembang dalam masyarakat." (Darmalaksana : Az zahra 2012 : 70)

Sementara itu dikalangan masyarakat kata Gender seringkali disalah artikan dengan Jenis kelamin, pedahal berbeda antara Gender dengan jenis kelamin. Jadi kajian tentang Gender bukanlah kajian Biologis tentang jenis 
kelamin akan tetapi merupakan kajian tentang hubungan, relasi, serta peran antara laki - laki dan perempuan di tengah - tengah Masyarakat.

Jajang Aep Saepudin menjelaskan Konsep Gender

Dalam Skripsinya dengan mengutip perkataan perkataan Hilary M. Lips dari bukunya yang berjudul sex and Gender sebagai berikut :

"Gender adalah harapan-harapan budaya terhadap lakilaki dan perempuan. Pendapat ini sejalan dengan pendapat umumnya kaum feminis seperti Linda L. Lindsey, yang menganggap semua ketetapan masyarakat perihal penentuan seorang laki-laki atau perempuan adalah termasuk bidang kajian gender" (Saepudin : Skripsi :24)

\section{Perbedaan Gender dengan Sex}

Sering terjadi orang salah mendefinitifkan kata Gender sehingga menyamakan antara konsep Gender dengen jenis kelamin (sex). Oleh karena itu, Untuk memahami konsep gender, harus ada pembedaan antara konsep gender itu sendiri dengan konsep jenis kelamin (sex).

Jenis kelamin (sex) merupakan pembagian dua jenis kelamin pada laki-laki dan perempuan yang ditentukan secara biologis dan memiliki sifat-sifat permanen yang tidak dapat berubah dan ditukarkan antara keduanya. Sifat tersebut merupakan kodrat yang diberikan oleh Tuhan kepada setiap laki-laki dan perempuan.

Sedangkan Gender menurut Mansour Fakih sebagaimana dikutip oleh Drs. Argyo Demartoto, MSi dalam makalahnya adalah:

"Pemilahan peran, fungsi, kedudukan, tanggung jawab antara laki-laki dan perempuan yang berfungsi untuk mengklasifikasikan perbedaan peran yang 
dikonstruksi secara sosial dan kultural oleh masyarakat, dan bersifat tidak tetap serta bisa dipertukarkan antar keduanya. Demartoto (Soft file Pdf :17)

Dalam kaitannya dengan ilmu sosial, gender adalah pembedaan antara laki-laki dan perempuan dalam bentuk sosial yang tidak disebabkan oleh perbedaan biologis yang menyangkut jenis kelamin (Soft file Pdf :17)

\section{Teori-Teori Gender}

Dalam pembahasan masalah Gender, sebetulnya tidak ada teori yang secara khusus menerangkan tentang Gender, akan tetapi teori - teori Gender ini di adopsi kemudian dikembangkan dari teori - teori para ahli yang ada kaitannya dengan masalah Gender seperti teori bidang sosial kemasyarakatan dan teori kejiwaan. Oleh karena itu, teori - teori masalah Gender banyak diambil dari teori Sosiologi dan Teori Psikilogi. Adapaun teori teori tersebut adalah:

\section{a. Teori Struktural - Fungsional}

Ini merupakan teori yang diadopsi dari teori Sosiologi yang diterapkan dalam sebuah struktur intitusi keluarga. Teori ini berangkat dari asumsi bahwa masyarakat itu terdiri dari beberapa bagian yang satu sama lain saling mempengaruhi. Marzuki mengutip dari perkataan Ratna megawangi mengatakan :

"Teori struktural-fungsional mengakui adanya segala keragaman dalam kehidupan sosial. Keragaman ini merupakan sumber utama dari adanya struktur masyarakat dan menentukan keragaman fungsi sesuai dengan posisi seseorang dalam struktur sebuah sistem. Sebagai contoh, dalam sebuah organisasi sosial pasti ada anggota yang mampu menjadi pemimpin, ada 
yang menjadi sekretaris atau bendahara, dan ada yang menjadi anggota biasa. Perbedaan fungsi ini bertujuan untuk mencapai tujuan organisasi, bukan untuk kepentingan individu. Struktur dan fungsi dalam sebuah organisasi ini tidak dapat dilepaskan dari pengaruh budaya, norma, dan nilai-nilai yang melandasi sistem masyarakat. Marzuki ( Soft File Pdf :5)

Jika dihubungkan dengan peran Gender, maka para pengikut teori ini akan menghubungkan teorinya dengan kehidupan manusia pada zaman pra industri dimana manusia pada masa itu hidup dengan cara berburu dan meramu. Tugas laki - laki adalah sebagai pemburu (hunter) membawa makanan kepada keluarga. Sementara perempuan bertugas hanya di sekitar rumah saja yaitu sebagai peramu (gatherer). Sebagai peramu perempuan hanya mengerjakan hal - hal yang terkait dengan reproduksi seperti mengandung, menyusui dan mengurus anak.

Teori ini banyak di tentang oleh kaum feminis dengan alasan teori ini hanya akan melanggengkan dominasi kaum laki - laki atas perempuan, sehingga laki - laki bisa menempati posisi - posisi publik sementara perempuan hanya menempati posisi domestik terutama masalah reproduksi.

Walaupun demikian teori ini tetap bertahan, karena dengan adanya pembagian peran antara laki laki dan perempuan telah terbukti membuat tatanan kehidupan bermasyarakat terjadi dengan seimbang.

b. Teori Sosial - konflik

Dalam masalah teori ini ,Marzuki menjelaskan dengan mengutip perkataan Ratna megawangi yang 
mengutip kuga dari prtkataan Lockwood yang mengatakan bahwa:

"Suasana konflik akan selalu mewarnai masyarakat, terutama dalam hal distribusi sumber daya yang terbatas. Sifat pementingan diri, menurutnya, akan menyebabkan diferensiasi kekuasaan yang ada menimbulkan sekelompok orang menindas kelompok lainnya. Perbedaan kepentingan dan pertentangan antar individu pada akhirnya dapat menimbulkan konflik dalam suatu organisasi atau masyarakat. Marzuki ( Soft File Pdf :7)

Dalam masalah Gender, Teori ini lebih banyak dipengaruhi oleh pemikiran karl Mark yang mengatakan bahwa terjadinya ketimpangan gender antara laki - laki dan perempuan itu terjadi bukan disebabkan oleh perbedaan dari segi biologis akan tetapi meupakan bagian dari penindasan kaum berkuasa dalam relasi produksi yang diterapkan dalam sistem keluarga. Hubungan antara suami dan istri tak ubahnya seperti hubungan ploretar dan borjuis, hamba dan tuan atau pemeras dengan yang diperas. Dengan kata lain Mark mengatakan bahwa ketimpangan peran gender dalam masyarakai itu bukan merupakan kodrat Tuhan tapi karena kontruksi masyarakat itu sendiri.

Menurut teori ini keluarga bukanlah suatu kesatuan yang normatif (harmonis dan seimbang) melainkan lebih dilihat sebagai sebuah sistem yang penuh konflik yang menganggap bahwa keragaman biologis dapat dipakai untuk melegitimasi relasi sosial yang operatif. Keragaman biologis yang menciptakan peran gender dianggap konstruksi budaya, sosialisasi kapitalisme, atau patriarkat. 
"Menurut para feminis Marxis dan sosialis institusi yang paling eksis dalam melanggengkan peran gender adalah keluarga dan agama, sehingga usaha untuk menciptakan perfect equality (kesetaraan gender 50/50) adalah dengan menghilangkan peran biologis gender, yaitu dengan usaha radikal untuk mengubah pola pikir dan struktur keluarga yang menciptakannya". Marzuki ( Soft File Pdf :8)

\section{c. Teori Feminisme Liberal}

Pada teori ini tidak ada perbedaan antara laki laki dan perempuan. Oleh karena itu perempuan harus mempunyai posri yang sama dengan laki laki. Akan tetapi walaupun pengikut teori ini beranggapan bahwa antara laki - laki dan perampuan tidak ada perbedaan, mereka tetap menolak untuk megatakan bahwa persamaan itu menyeluruh. Hal ini diakui oleh mereka tetap ada beberapa perbedaan yang disebabkan oleh berbedanya organ reproduksi wanita yang menyebabkan adanya konsekwensi dari organ tersebut. Hal ini di jelaskan oleh Marzuki dengan mengutip dari Ratna megawangi sebegai berikut :

"Teori ini berasumsi bahwa pada dasarnya tidak ada perbedaan antara laki-laki dan perempuan. Karena itu perempuan harus mempunyai hak yang sama dengan laki-laki. Meskipun demikian, kelompok feminis liberal menolak persamaan secara menyeluruh antara laki-laki dan perempuan. Dalam beberapa hal masih tetap ada pembedaan (distinction) antara laki-laki dan perempuan. Bagaimanapun juga, fungsi organ reproduksi bagi perempuan membawa konsekuensi logis dalam kehidupan bermasyarakat" Marzuki (Soft file Pdf :9) 
Para pengikut teori ini menuntut supaya kaum perempuan bisa masuk dalam kegiatan - kegiatan di luar rumah, sementara perbedaan organ reproduksi bukan merupakan penghalang bagi perempuan untuk memasuki pekerjaan di sektor sektor publik.

\section{d. Teori Feminisme Marxis - Sosialis}

Tujuan utama dari gerakan feminisme ini adalah mengadakan penataan ulang kembali tatacara kehidupan bermasyarakat supaya tercapai kesetaraan Gender. Mereka beranggapan bahwa telah terjadinya ketimpangan gender itu disebabkan karena sistem kapitalis yang menyebakan adanya kelas - kelas, termasuk dalam keluarga.

Menurut Marzuki Gerakan kelompok ini mengadopsi teori praxis Marxisme, yaitu teori penyadaran pada kelompok tertindas, agar kaum perempuan sadar bahwa mereka merupakan 'kelas' yang tidak diuntungkan. Proses penyadaran ini adalah usaha untuk membangkitkan rasa emosi para perempuan agar bangkit untuk merubah keadaan. Marzuki (Soft file Pdf :10)

\section{e. Teori Feminisme Radikal}

Teori ini berkembang pesat di Amerika Serikat pada kurun waktu 1960-an dan 1970-an. Meskipun teori ini hampir sama dengan teori feminisme Marxis-sosialis, teori ini lebih memfokuskan serangannya pada keberadaan institusi keluarga dan sistem patriarki. Keluarga dianggapnya sebagai institusi yang melegitimasi dominasi laki-laki (patriarki), sehingga perempuan tertindas. Feminisme ini cenderung membenci laki-laki sebagai individu dan mengajak perempuan untuk mandiri, bahkan tanpa perlu keberadaan laki-laki 
dalam kehidupan perempuan. Elsa Gidlow mengemukakan teori bahwa menjadi lesbian adalah telah terbebas dari dominasi laki-laki, baik internal maupun eksternal. Martha Shelley selanjutnya memperkuat bahwa perempuan lesbian perlu dijadikan model sebagai perempuan mandiri. Marzuki(Soft file Pdf : 11).

Karena keradikalannya, teori ini mendapat kritikan yang tajam, bukan saja dari kalangan sosiolog, tetapi juga dari kalangan feminis sendiri. Tokoh feminis liberal tidak setuju sepenuhnya dengan teori ini. Persamaan total antara laki-laki dan perempuan pada akhirnya akan merugikan perempuan sendiri. Laki-laki yang tidak terbebani oleh masalah reproduksi akan sulit diimbangi oleh perempuan yang tidak bisa lepas dari beban ini.

\section{f. Teori Ekofeminisme}

Teori Ekofeminisme ini muncul akibat dari ketidak puasan terhadap perkembangan ekologi manusia yang semakin hancur. Akibat dari adanya persamaan Gender sehingga memungkinkan masuknya perempuan ke kancah publik sehingga menimbulkan pudarnya sifat feminim dari perempuan, akhirnya melahirkan perempuan perempuan peniru laki - laki.

Akibatnya akan timbul berkurangnya rasa cinta, rasa kasih, merebaknya tindakan kriminalisme, banyaknya perempuan yang menelantarkan anaknya. Maka pada akhirnya kehidupan peradaban manusia tidak lagi stabil.

\section{Gerakan Feminisme untuk kesetaraan gender}

Tentang konsep kesetaraan Gender muncul yang namanya Gerakan feminisme yang diawali dari adanya konsep kesetaraan ( al musawah atau equality) dan 
ketidaksetaraan. Prof. Dr. H. Afiudin, M.M dalam makalahnya dengan mengutip dari perkataan Jalaludi Rahmat menyebutkan bahwa ada tiga madzhab gerakan feminisme, yaitu :

1) Feminisme liberal

Madzhab ini menekankan persamaan laki - laki dan perempuan dengan berpijak pada liberalisme politik. Pada madzhab ini perempuan mempunyai kedudukan sama dimata hukum dan sosial dengan laki - laki sehingga harus ada kesetaraan dalam hukum, kebiasaan dan nilai - nilai.

2) Feminisme Kultural

Madzhab ini menganggap bahwa perilaku unik perempuan telah direndahkan di masayarakat, sifat sifat khas perempuan harus mendapatkan tempat dan harus dihargai, jadi antara laki - laki dan perempuan tidak harus sama akan tetapi harus berdampingan sehingga akan menimbulkan kombinasi yang baik dalam kehidupan keluarga maupun masyarakat.

3) Feminisme radikal

Madzhab ini menganggap bahwa struktur sosial dimanapun dan dalam jenis masyarakat manapun senantiasa menguntungkan laki - laki. Kekuasaan, agama, hukum semuanya dijadikan alat untuk memperlakukan perempuan secara diskriminatif.

Afiudin juga mengutip perkataan Riffat Hasan yang mengatakan bahwa kriteria kesetaraan Gender adalah:

1) Tidak ada jenis kelamin yang tersubordinasi oleh jenis kelamin lainnya.

2) Tidak ada marginalisasi terhadap jenis kelamin dengan mengurangi atau menutup kesempatan.

3) Bebas dari stereotype yang sebenarnya hanya mitos 
4) Tidak ada yang menanggung lebih berat daripada yang lain.

\section{B. METODE}

Pendekatan yang digunakan dalam penilitian ini adalah pendekatan kualitatif. Sebagaimana yang diungkapkan oleh Sugiyono, (2012: 7-8) bahwa metode kualitatif adalah metode penelitian yang berlandaskan filsafat pospositivisme, digunakan untuk meneliti pada objek yang alamiyah.

Adapun metode yang digunakan dalam penelitian ini adalah metode content analysis, yang pada awalnya digunakan disiplin ilmu komunikasi dan dapat dimanfaatkan untuk penelitian yang bersifat normatif.

Teknik pengumpulan data yang digunakan dalam penelitian ini adalah studi kepustakaan. Studi kepustakaan ini dilakukan dengan cara melakukan pengkajian terhadap buku dan literatur yang berkaitan dengan apa yang akan diteliti, dengan buku Tafsir Al Azhar karya KH. Abdul Karim Amrulloh ( Buya Hamka) sebagai sumber primernya.

Adapun teknik yang digunakan dalam menganalisis data pada karya tulis ini adalah dengan cara :

1. Data Reduction (Reduksi data)

Yaitu proses berfikir sensitive yang memerlukan kecerdasan, keluasan dan kedalaman wawasan yang tinggi. Dalam hal ini penulis melakukan kajian terhadap berbagai buku Sumber yang kiranya bisa dijadikan referensi untuk menjawab permaslahan yang dibahas pada skripsi ini.

2. Data Display (Penyajian data)

Yaitu penyajian data dalam bentuk uraian singkat dengan teks yang bersifat naratif. Dengan mencampurkan teori teori serta panafsiran - penafsiran para Ulama dengan teknik satu Buku dijadikan sebagai referensi Utama dan yang lainnya sebegai penunjang atau pelengkap supaya permasalahan yang di teliti tampak semakin jelas.

3. Conclusion Drawing 
Yaitu penarikan kesimpulan yang kemungkinan akan merubah kesimpulan semula yang telah ditetapkan

Adapun langkah - langkah yang dilakukan penulis Dalam penelitian ini, penulis mencari pengertian gender secara umum berdasarkan pendapat para ahli. Kemudian menganalisis bagaimana konsep pendidikan gender dalam islam berdasarkan al-Qur'an melalui tafsir Al Azhar Karya Buya Hamka. Sehingga ditemukan sebuah pemahaman konsep pendidikan gender dalam islam bedasarkan alQur'an, yang dikhususkan dalam surat al Hujrot ayat 13. Maka disusunlah rencana pengujian keabsahan Data melalui struktur dibawah ini.

\section{DISKUSI}

Setelah mengkaji Gender dalam presfektip Ahli pendidikan dilanjutkan dengan menela'ah Tafsir Surat Al Hujurot ayat 13 dengan menggunakan Tafsir Al Azhar Karya Prof. Dr. Buya Hamka sebagai bahan primer atau Pokok, serta menggunakan kitab - kitab Tafsir lainnya sebagai pembanding, maka dapat ditemukan bahwa bawa :

1. Agama Islam tidak mengajarkan sistem ketidak setaraan Gender, karena sangat jelas dalam surat Al Hujurot ayat 13 dijelaskan bahwa antara laki - laki dan perempuan itu memiliki asal - usul yang sama. Mereka berasal dari seorang laki - laki (Bapak) dan seorang Perempuan (Ibu). Juga bahan pembuatannya sama yaitu sari pati air mani laki - laki yang bercampur dengan sel telur perempuan.

Jika dalam agama Islam ada beberapa permasalahan yang sifatnya seolah - olah membedabedakan gender itu bukan merupakan ajaran diskriminasi Gender akan tetapi merupakan keadilan Allah terhadap makhluk ciptaannya. Ada beberapa hal yang seolah olah merupakan diskrimnasi Gender dalam Islam, seperti: 
a. Pembagian Harta warisan

Ayat yang menjelaskan tentang bagian harta warisan yang membedakan antara laki - laki dan perempuan adalah surat An Nisa ayat 11, yang artinya :

"Allah mensyari'atkan bagimu tentang (pembagian pusaka untuk) anak-anakmu. Yaitu : bahagian seorang anak lelaki sama dengan bagahian dua orang anak perempuan; dan jika anak itu semuanya perempuan lebih dari dua, (Tim Penerjemah Al Qur'an Kemenag RI, 2012 :78)

Dalam ayat ini Allah menjelaskan bahwa bagian anak laki - laki setara dengan dua bagian anak perempuan. Jika dilihat dari sepintas maka seolah olah diskriminasi terhadap kaum perempuan akan tetapi bukan. Karena adil itu bukan memberikan sesuatu sama rata akan tetapi membagikan sesuatu disesuaikan dengan tingkat kebutuhannya atau sering disebut dengan proporsional.

Kaum laki - laki diberikan kelebihan oleh Allah berupa tenaga yang kuat, sehingga menjadi konsekwensi bahwa laki - laki merupakan kepala keluarga yang harus membiayayi seluruh anggota keluarga dari mulai istri serta anak - anaknya. Oleh karena itu tanggung jawab serta beban yang dipilkul kaum laki - laki sngat banyak tidak sebanding dengan beban yang dipikul oleh seorang istri.

Maka akan sangat adil dalam pembagian harta warisan, bagian laki - laki lebih besar dari bagian perempuan.

b. Pernikahan

Dalam pernikahan perempuan dilarang melakukan pernikahan dengan banyak suami (Polyandri) sementara laki - laki diperbolehkan menikahi lebih dari sati istri dengan batas maksimal sampai empat. 
Ayat Al Qur'an yang menjelaskan hal ini adalah surat An Nisa ayat 3, yang artinya :

"Dan jika kamu takut tidak akan dapat Berlaku adil terhadap (hak-hak) perempuan yang yatim (bilamana kamu mengawininya), Maka kawinilah wanitawanita (lain) yang kamu senangi : dua, tiga atau empat. kemudian jika kamu takut tidak akan dapat Berlaku adil, Maka (kawinilah) seorang saja, atau budak-budak yang kamu miliki. yang demikian itu adalah lebih dekat kepada tidak berbuat aniaya". ( Tim Penerjemah Al Qur'an Kemenag RI, 2012 : 77)

Ayat ini bukan merupakan diskriminasi Gender akan tetapi disesuaikan dengan fungsi jenis kelamin yang dimiliki oleh laki - laki dan perempuan.

Dalam hal pendidikan, Agama islam tidak mengajarkan bahwa yang harus belajar ilmu itu merupakan hak kaum laki - laki, akan tetapi semua mukminin dan mukminat itu mempunyai kewajiban yang sama dalam hal kewajiban menuntut ilmu serta mempunyai hak yang sama untuk mendapatkan ilmu. Hal ini dibuktikan dengan Hadits perintah menuntut ilmu sebagai berikut :

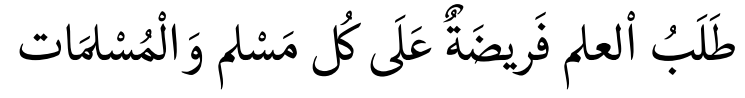

Artinya :

Menuntut ilmu itu di fardukan kepada seluruh muslim dan muslimat. (Az Zarnuji : 4)

2. Adananya Bangsa - bangsa itu bukan untuk saling menghinakan atau saling menjajah, akan tetapi semata mata agar kita mudah mengenal satu sama lain.

3. Islam tidak mengajarkan bahwa yang paling mulia adalah laki - laki dan bukan perempuan. Akan tetapi islam mengajarkan bahwa yang paling mulia itu adalah orang 
yang paling bertaqwa apapun bangsanya, apapun bahasanya dan apapun jenis Gender nya.

\section{Nilai - Nilai Gender dan Manfaat Pendidikan Gender dalam Islam \\ 1. Nilai - nilai Gender dalam Islam}

Setelah melakukan pembahasan secara total dari Al Qur'an surat Al Hujurot ayat 13, maka akan dapat ditemukan ada beberapa nilai Gender dalam Islam dimana islam sama sekali tidak melakukan diskrimanasi Gender. Adapun nilai nilai gender dalam islam itu diantaranya :

a. Dilihat dari asal mula kejadiannya semua manusia yang terlahir melalui proses penciptaan secara alami semuanya sama berasal dari seorang ayah dan Ibu yang merupakan percampuran antara air mani ayah dan sel telur ibu. Disini tampak jelas bahwa antara laki - laki dan perempuan melewati proses penciptaan yang sama.

b. Dalam hal pernikahan ketika laki - laki punya hak untuk menjatuhkan kepada istri maka istri pun punya hak untuk khulu' atau membeli talaq kepada suami.

c. Dalam hal fasakh nikah, ketika suami punya hak untuk mengembalikan istri kepada keluarganya karena ada penyakit seperti tertutup lubang vaginanya dengan daging atau tulang, karena istri menjadi gila, maka istri juga sama punya hak untuk megembalikan suami pada keluarganya jika suami punya penyakit seperti impotensi atau gila.

d. Dalam hal kepemimpinan. Islam memang memerintahkan bahwa untuk menduduki posisi kepemimpinan publik itu harus laki - laki, tapi hal ini tidak menutup kesempatan kepada perempuan untuk menduduki posisi itu. Ketika di suatu negeri tidak ada laki-laki yang kompeten untuk menduduki posisi kepemimpinan maka perempuan tidak dilarang untuk menduduki posisi itu. Terjadinya hal ini bukan berarti mengkelas duakan perempuan ketimbang laki - laki, 
akan tetapi karena adanya pembagian tugas yang sama penting antara laki - laki dan perempuan dimana perempuan tugas pokonya adalah merawat, mengurus serta mendidik anak supaya menjadi generasi yang hebat.

e. Dalam hal tugas dan fungsi sebagai manusia, Allah memberikan tugas dan fungsi yang sama kepada seluruh manusia yaitu untuk menjadi kholifah di muka Bumi serta senantiasa beribadah kepada Allah. Firman Allah dalam surat Al Baqoroh ayat 30, yang artinya:

"Ingatlah ketika Tuhanmu berfirman kepada Para Malaikat: "Sesungguhnya aku hendak menjadikan seorang khalifah di muka bumi." mereka berkata: "Mengapa Engkau hendak menjadikan (khalifah) di bumi itu orang yang akan membuat kerusakan padanya dan menumpahkan darah, Padahal Kami Senantiasa bertasbih dengan memuji Engkau dan mensucikan Engkau?" Tuhan berfirman: "Sesungguhnya aku mengetahui apa yang tidak kamu ketahui." (Tim Penerjemah Al Qur'an Kemenag RI 2012)

f. Dalam hal warisan, Perempuan diberikan bagian setengah dari bagian laki - laki, ini disesuaikan dengan tanggung jawab yang dibebankan, dimana laki - laki bertanggung jawab akan nafkah keluarganya sementara perempuan itu akan di tanggung jawab oleh suaminya.

\section{Manfaat Pendidikan Gender dalam Islam}

Dengan adanya pendidikan Gender dalam Islam maka akan ada beberapa manfaat yang akan di dapat, di antaranya :

a. Lahirnya sikap saling menghormati dan menghargai antara kaum laki - laki dan perempuan.

b. Akan menghilangkan kebiasaan dominasi Gender dimana segala sesuatu harus mengutamakan laki - laki sementara perempuan selalu dikelas dua kan.

c. Akan terciptanya pembagian tugas yang baik antara laki - laki dan perempuan. 
d. Akan timbul ketaatan terhadap aturan warisan dalam islam, karena dengan mempelajari Gender dalam Islam, maka semua akan dapat memahami kedudukan dan fungsi masing - masing.

\section{KESIMPULAN}

Berdasarkan rumusan permasalahan yang telah disebutkan di awal serta setelah melakukan berbagai pembahasan, maka dapat diambil beberapa kesimpulan sebagai berikut:

1. Konsep Gender dalam presfektif pendidikan Islam adalahIslam mewajibkan kepada setiap individu muslim dan muslimat supaya mereka mau belajar menuntut ilmu pengetahuan sebagai bekal mereka hidup dan menjalankan tugas serta fungsinya di dunia ini yaitu sebagai Kholifah. Kewajiban menuntut ilmu ini bersifat umum tanpa membeda - bedakan status Gender.

2. Tafsir Surat Al Hujurot ayat 13 menurut Tafsir Al Azhar karya Buya Hamka terdapat konsep kesetaraan gender, diantaranya : a) Allah menyeru seluruh manusia tanpa membeda-bedakan jenis kelamin, jenis kulit atau yang lainnya. Ini menunjukan bahwa seluruh umat manusia pada hakikatnya sama, tidakada yang lebih unggul dari yang lainnya. b) Manusia tidak bisa memilih agar dilahirkan di suku atau bangsa tertentu. Karenanya, manusia tidak pantas membanggakan dirinya atau melecehkan orang lain karena faktor suku atau bangsa. c) Allah swt menetapkan parameter lain untuk mengukur derajat kemulian manusia, yaitu ketakwaan. Kadar ketakwaan inilah yang menentukan kemulian dan kehinaan seseorang.

3. Konsep Gender dalam Islam berdasarkanAl Qur'ansurat Al $\begin{array}{llll}\text { Hujurotayat } & 13 & \text { berdasarkanTafsir }\end{array}$ AzharKaryaBuyaHamkaadalah Islammengajarkan adanya kesetaraan Gender karena semua manusia dengan jenis kelamin apapun sama - sama berasal dari laki - laki dan 
perempuan serta merupakan campuran dari seperma laki laki dan sel telur perempuan.

\section{E. DAFTAR PUSTAKA}

Ad-Dimasyqi, Abul Fida' Ismail bin Katsir. (2008). Tafsir Al Qur'an al-'Azhim. Sinar Baru Algesindo Offset Bandung.

Afifudin dkk. (2012) Az Zahra Jurnal Studi Wanita dan Islam.

Pusat Studi Wanita UIN Sunan Gunung Djati Bandung.

As Syaukani, Muhammad bin Ali bin Myhammad (PDF File)

Fathul Qodir Daarul Wafa.

Al Qurtuby, Abu Abdillah Muhammad bin Ahmad bin Abi

Bakrin (2006). Al Jami'ul al ahkamil al Qur'an

Mu'assasah Ar Risalah. Libanon.

Az Zamakhsayari, Abu Qosim Mahmud bin Umar (1998). Al Kasyaf Maktabah Al Ubaikan Riyadh Saudi Arabia.

Al Baghowi, Abi Muhammad Husen bin Mas'ud (1412) Tafsir Al Baghowi Ma'alimi Tanzil Daarut At Toyibah Riyadh Saudi Arabia.

Al Maraghi, Ahmad Mustofa (1946) Tafsir Al Maraghi

Maktabah Al Mustofa Al Bani Al Halby Mesir.

Fakhrudin, Muhammad Ar Razi (1981) Tafsir Al Fakhrurozi

Daarul Fikr Beirut Libanon

Fakultas Tarbiyah IAILM. (2015). Pedoman Penuliasan Karya

Tulis Ilmiyah Fakultas Tarbiyah (IAILM) Suryalaya

Tasikmalaya Jawa Barat

Hamka (1997). Tafsir Al Azhar. PT Pustaka Panjimas Jakarta

Majelis Permusyawaratan Rakyat (2013) Undang - Undang

Dasar Negara Republik Indonesia Tahun 1945

Sekretariat Jenderal MPR RI

Marzuki (PDF File) Kajian awal tentang Teori-Teori Gender.

Priatin Eka dkk (2008) Konsep Pendidikan PT Karsa Mandiri

Persada Bandung. 
Quraish Shihab, Muhammad. (2006) Tasir Al Misbah Pesan, Kesan dan Keserasian Al Qur'an . Lentera Hati. Jakarta Quraish Shihab, Muhammad. (2006) Wawasan Al Qur'an . Mizan Bandung.

Suryana Yana. (2015) Gender dalam Pendidikan. Cahaya Atma Pustaka Universitas atma jaya Jogjakarta

.Sugiyono (2012) Metode Penelitian Kuantitatif Kualitatif dan $R \& D$ Alabeta Bandung.

Shaleh dkk (2009) Asbabun Nuaul Latar belakang historis turunnya ayat - ayat Al Qur'an CV. Diponegoro Bandung.

Sumantri, Endang dkk (2006) Konsep Dasar Pendidikan Nilai PT Pribumi Mekar Bandung.

Sukmadinata, Nana Syaodih (2010) Metode Penelitian Pendidikan PT Remaja Rosdakarya Bandung 